\title{
KONSISTENSI DAN PENGARUH IMPLEMENTASI UNDANG-UNDANG NOMOR 1 TAHUN 1974 TENTANG PERKAWINAN TERHADAP PRAKTEK PERKAWINAN BEDA AGAMA DI MAKASSAR
}

\section{(Consistency And Influence of the Implementation of the Law No. 1 of 1974 regarding Marriage to the Interfaith Marriage Practices in Makassar)}

\author{
Andika Prawira Buana \\ Fakultas Hukum Universitas Muslim Indonesia \\ Jl. Urip Sumoharjo No.225 Makassar \\ Email: andika.prawira@umi.ac.id \\ Tulisan Diterima: 31-08-2017; Direvisi: 31-10-2017; Disetujui Diterbitkan: 09-11-2017
}

\begin{abstract}
The City of Makassar with its pluralistic society possesses high possibilities of seeing marriages between two persons of different religions, while the existing regulations, the Law no. 1 of 1974 about the marriage is very clear about impossibility of interfaith marriage. Therefore, the main subject of this study is the government's consistency in dealing with the practices of interfaith marriages, especially in the city of Makassar, and the influence of interfaith marriage in the family. This research uses qualitative type with empirical juridical approach. This study uses primary and secondary data while the data are collected by means of documents, face-to-face interviews, and questionnaires. Respondents in this study are people who have married to a spose with different faith, ordinary people, and employees of Makassar's civil registration office. The sampling method in this research is the "purposive sampling". The number of samples in this study has been defined 100 respondents consisting of six persons involved in interfaith marriage, 80 ordinary people, and 14 civil registry office employees of the City of Makassar. The results of this study demonstrates inconsistency of the government in the implementation of the Law No. 1 of 1974 regarding marriage in relation to the interfaith marriage practices rampant in the city of Makassar and the negative influence the interfaith marriage may posses to the family.
\end{abstract}

Keywords: Influence, Implementation, Interfaith Marriage

\begin{abstract}
ABSTRAK
Kota Makassar yang memiliki masyarakat yang pluralistik sangat memungkinkan untuk terjadinya perkawinan diantara dua orang pemeluk agama yang berlainan, sementara aturan yang ada berdasarkan UU No. 1 Tahun 1974 tentang perkawinan sangat jelas tidak dimungkinkannya perkawinan beda agama. Oleh sebab itu masalah pokok pada penelitian ini bagaimanakah konsistensi pemerintah dalam menyikapi praktek perkawinan beda agama khususnya kota Makassar, dan bagaimana pengaruh perkawinan beda agama dalam keluarga. Penelitian ini menggunakan tipe kualitatif dengan pendekatan yuridis empiris. Penelitian ini menggunakan data primer dan sekunder dengan teknik pengumpulan data yakni dokumentasi, wawancara tatap muka, dan menyebarkan kuesioner. Responden dalam penelitian ini adalah masyarakat yang menjadi pelaku perkawinan beda agama, masyarakat biasa, dan pegawai dinas catatan sipil kota Makassar. Metode pengambilan sampel dalam penelitian ini adalah menggunakan metode "purposive sampling". Jumlah sampel dalam penelitian ini ditentukan sebanyak 100 orang responden yang terdiri dari 6 pelaku perkawinan beda agama, 80 masyarakat biasa, dan 14 pegawai dinas catatan sipil kota Makassar. Hasil penelitian ini menjawab tidak konsistensinya pemerintah terhadap implementasi UU No. 1 Tahun 1974 tentang perkawinan terhadap praktek perkawinan beda agama yang terjadi di kota Makassar dan pengaruh negatif yang ditimbulkan dalam keluarga akibat perkawinan beda agama.
\end{abstract}

Kata Kunci: Pengaruh, Implementasi, Perkawinan Beda Agama 


\section{PENDAHULUAN}

Perkawinan merupakan ikatan yang sangat dalam dan kuat sebagai penghubung antara seorang pria dengan seorang wanita dalam membentuk suatu keluarga. Dalam membentuk suatu keluarga tentunya memerlukan suatu komitmen yang kuat di antara pasangan tersebut sehingga dalam hal ini perkawinan di Indonesia diatur oleh UU No. 1 Tahun 1974 tentang Perkawinan. Oleh karenanya dalam UU yang sama diatur bahwa perkawinan adalah sah apabila dilakukan menurut hukum masing-masing agama dan kepercayaan itu serta telah dicatat menurut peraturan perundangundangan yang berlaku. ${ }^{1}$

Landasan hukum agama dalam melaksanakan sebuah perkawinan merupakan hal yang sangat penting dalam UU No. 1 Tahun 1974, sehingga penentuan boleh tidaknya perkawinan tergantung pada ketentuan agama. Hal ini berarti juga bahwa hukum agama menyatakan perkawinan tidak boleh, maka tidak boleh pula menurut hukum negara. Namun bagaimana dengan perkawinan beda agama. Perkawinan beda agama bukanlah perkawinan campuran dalam pengertian hukum nasional kita karena perkawinan campuran menurut Undang-undang perkawinan disebut sebagai perkawinan yang terjadi antara WNI dengan WNA, akan tetapi perkawinan beda agama di masyarakat sering pula disebut sebagai perkawinan campuran. Untuk memudahkan tulisan ini hanya akan menggunakan istilah perkawinan beda agama.

UU Perkawinan sendiri penafsiran resminya hanya mengakui perkawinan yang dilangsungkan berdasarkan agama dan kepercayaan yang sama dari dua orang yang berlainan jenis yang hendak melangsungkan perkawinan. Kenyataan dalam kehidupan masyarakat pluralistik seperti Indonesia, realitasnya tidak dipungkiri, sangat mungkin terjadinya perkawinan diantara dua orang pemeluk agama berlainan. Beberapa diantaranya mempunyai kelimpahan materi mungkin tidak terlampau pusing karena bisa menikah di negara lain, namun bagaimana yang kondisi ekonominya terbatas tentu ini menimbulkan suatu masalah hukum.

Meskipun sudah dilarang, perkawinan beda agama masih terus dilakukan. Berbagai cara ditempuh, demi mendapatkan pengakuan dari Negara. Ada beberapa cara yang populer ditempuh pasangan beda agama agar pernikahannya dapat dilangsungkan.

1. Pagi menikah sesuai agama laki-laki, siangnya menikah sesuai dengan agama perempuan.

2. Salah satu dari calon pengantin baik laki-laki ataupun perempuannya mengalah mengikuti agama pasangannya, lalu setelah menikah dia kembali kepada agamanya.

3. Menikah di luar negeri.

Perkawinan antar agama yang terjadi dalam kehidupan masyarakat seharusnya tidak terjadi jika dalam hal ini Negara atau pemerintah secara tegas melarangnya dan menghilangkan sikap mendua dalam mengatur dan melaksanakan suatu perkawinan bagi rakyatnya. Sikap ambivalensi pemerintah dalam perkawinan beda agama ini terlihat dalam praktek bila tidak dapat diterima oleh Kantor Urusan Agama (KUA) dapat dilakukan di kantor catatan sipil dan menganggap sah perkawinan berbeda agama yang dilakukan di luar negeri.

Jadi penentuan boleh tidaknya bergantung pada hukum agama dan seluruh pemeluk agamanya wajib menaatinya. Merujuk pada Undang-undang Perkawinan Nomor 1 Tahun 1974 Pasal 2 Ayat (1) terhadap beberapa hal di atas, maka pemerintah menyerahkan sepenuhnya kepada hukum agama masing-masing pihak untuk menentukan diperbolehkan atau dilarangnya perkawinan beda agama.

Perkawinan beda agama merupakan ikatan lahir dan batin antara seorang pria dan seorang wanita, yang karena berbeda agama menyebabkan tersangkutnya dua peraturan yang berlainan mengenai syarat-syarat dan tata cara pelaksanaan perkawinan sesuai dengan hukum agamanya masing-masing, dengan tujuan untuk membentuk keluarga bahagia dan kekal berdasarkan Ketuhanan Yang Maha Esa. Pada umumnya menurut hukum agama perkawinan adalah perbuatan suci (sakramen, samskara), yaitu suatu perikatan antara dua pihak dalam memenuhi perintah dan anjuran Tuhan Yang Maha Esa, agar kehidupan berkeluarga dan berumah tangga serta

1. Abdurrahman, Kompilasi Hukum Islam Indonesia, (Jakarta: Akademika Pressindo, 2010) h. 114. 
berkerabat berjalan dengan baik sesuai dengan ajaran agama masing-masing. Jadi perkawinan dilihat dari segi keagamaan adalah suatu perikatan jasmani dan rohani yang membawa akibat hukum terhadap agama yang dianut kedua calon mempelai beserta keluarga kerabatnya. Hukum agama telah menetapkan kedudukan manusia dengan iman dan taqwanya, apa yang seharusnya dilakukan (dilarang). Oleh karenanya pada dasarnya setiap agama tidak dapat membenarkan perkawinan yang berlangsung tidak seagama. ${ }^{2}$

Yang dimaksud dalam beda agama disini adalah perempuan muslim dengan laki-laki nonmuslim dan sebaliknya laki-laki muslim dengan perempuan nonmuslim. Keduanya boleh melakukan pernikahan apabila pihak yang nonmuslim tersebut telah masuk Islam. Tentang larangan kawin beda agama disebutkan dalam Pasal 40 Kompalasi Hukum Islam Indonesia yang diberlakukan berdasarkan Instruksi Presiden Nomor 1 Tahun 1991 disebutkan bahwa :

"Dilarang melangsungkan perkawinan antara seorang pria dan wanita, karena wanita tersebut tidak beragama Islam".

Berdasarkan ketentuan ini dapat diketahui bahwa tidak ada perkawinan beda agama, bagi pihak-pihak yang ingin melaksanakan perkawinannya, mereka harus memilih agama yang dianut oleh pihak istri atau pihak suami. Tidak ada lagi setelah nikah di Kantor Urusan Agama Kecamatan lalu pindah menikah di Gereja atau Catatan Sipil. ${ }^{3}$

Sudah jelas disini tidak ada perkawinan beda agama, begitu juga fatwa yang telah dikeluarkan oleh MUI (Majelis Ulama Indonesia), tidak mengijinkan seorang pria melakukan perkawinan dengan ahli kitab meskipun dalam Al-quran diperbolehkan. Fatwa melarang perkawinan seperti itu karena kerugian lebih besar dari pada keuntungannya, selain itu rupanya telah didorong oleh keinsyafan akan adanya persaingan keagamaan. Maka sudah selayaknya ketentuan tersebut dalam Pasal Kompalasi Hukum Islam Indonesia tetap dipertahankan. Dilarang melangsungkan perkawinan antara seorang pria atau wanita Islam dengan wanita atau pria tidak beragama Islam. Ijma' ulama Indonesia tentang masalah ini harus tetap dipertahankan dan harus ditingkatkan dalam peraturan perundang-undangan di masa yang akan datang. ${ }^{4}$

Sebuah dokumen yang berbentuk surat terbuka yang dikeluarkan oleh Majelis Ulama daerah Jakarta yang di dalamnya juga memberikan perincian apabila terjadi masalah perkawinan agama menyatakan bahwa apabila suatu perkawinan antara seorang pria Islam dan seorang wanita bukan Islam hendak dilaksanakan, maka upacara perkawinan seharusnya dilakukan di Kantor Urusan Agama (KUA) menurut peraturan agama Islam. Kepada para pegawai kantor Dinas Catatan Sipil, yang mencatat perkawinanperkawinan bukan-Islam, surat itu meminta dengan sangat agar menghormati kepercayaan mereka di kantor tersebut. Jika seorang diantara mereka adalah seorang beragama Islam, surat itu meminta Kantor Dinas Catatan Sipil agar menganjurkan pasangan pengantin itu untuk mendaftarkan perkawinannya di Kantor Urusan Agama (KUA). Surat itu menegaskan bahwa hal itu adalah sesuai dengan asas Pancasila, Undang Undang Dasar 1945, dan Undang-Undang Perkawinan tahun 1974.

Ketua Komisi VIII (bidang keagamaan) DPR Saleh Partaonan Daulay mengatakan, aparatur Negara di instansi pusat maupun daerah tidak boleh lagi memfasilitasi atau meloloskan pencatatan nikah beda agama. Hal ini menyusul putusan Mahkamah Konstitusi (MK) yang menguatkan bahwa nikah beda agama tidak bisa dilakukan di Indonesia. Semua instansi pemerintah diminta konsisten tidak melayani nikah beda agama.

Selama ini banyak laporan bahwa ada sekelompok masyarakat yang memfasilitasi perkawinan beda agama. Kemudian mereka mencatatkan perkawinan beda agama itu ke dinas pencatatan sipil. Perkawinan tidak sebatas urusan pencatatan administrasi saja, tetapi juga terkait dengan persoalan spiritual dan sosial. Maka dari itu demi kepastian hukum, perkawinan seharusnya tidak melanggar undang-undang dan diakui dalam pencatatan perkawinan.

2. Hilman Hadikusuma, Hukum Perkawinan Indonesia menurut Perundangan Hukum Adat Hukum Agama, (Bandung: Mandar Maju, 2007) h. 10.

3. Abdul Manan, Aneka Masalah Hukum Perdata Islam di Indonesia,(Jakarta: Kencanaprenada Media Group, 2008$)$, h. 28.

4. Abdurrahman, Kompilasi Hukum Islam Indonesia, h. 114. 
Dirjen Bimbingan Masyarakat Islam (Bimas) Kementerian Agama, Machasin mengatakan, pelayanan pencatatan nikah tidak ada perubahan atau ketentuan baru, sebab putusan MK pada prinsipnya menguatkan ketentuan yang selama ini dijalankan oleh pemerintah. "pencatatan nikah dilakukan pemerintah setelah mendapatkan persetujuan dari otoritas masing-masing agama. Ada beberapa alasan yang diambil MK dalam memutuskan gugatan aturan nikah beda agama itu, di antaranya adalah sebagai Negara ketuhanan, maka perbuatan yang dilakukan oleh warga Negara harus mempunyai hubungan erat dengan agama. Termasuk urusan pernikahan atau perkawinan, MK juga beralasan bahwa Negara berperan melindungi warga Negara dalam membentuk keluarga dan melanjutkan keturunan melalui perkawinan yang sah. $^{5}$

Berdasarkan deskripsi permasalahan di atas tulisan ini mengangkat dua pokok masalah yaitu: pertama, bagaimana konsistensi implementasi Undang-Undang Nomor 1 Tahun 1974 tentang Perkawinan terhadap praktek perkawinan beda agama di Makassar; kedua, bagaimanakah pengaruh perkawinan beda agama dalam keluarga.

\section{METODE PENELITIAN}

Tipe pada penelitian ini adalah kualitatif dengan pendekatan yuridis sosiologis. Penelitian ini berlangsung di Dinas Catatan Sipil Kota Makassar. Populasi penelitian ini adalah warga masyarakat baik yang menjadi pelaku praktek perkawinan beda agama, masyarakat biasa, dan pegawai Kantor Dinas Catatan Sipil Kota Makassar. Pengambilan sampel dilakukan dengan bentuk Purposive Sampling. Data pimer dianalisis berdasarkan deskriptif kualitatif dan data sekunder dianalisis berdasarkan deskriptif kuantitatif dalam bentuk tabulasi frekuensi dan distribusi presentase dengan rumus:

$$
\mathrm{f}
$$

$\mathrm{P}=$ X $100 \%$

$\mathrm{N}$

Keterangan :

$\mathrm{P}=$ Persentase

$$
\begin{aligned}
& \mathrm{f}=\text { Frekuensi } \\
& \mathrm{N}=\text { Jumlah Sampel } \\
& \%=\text { Pembulat }
\end{aligned}
$$

\section{PEMBAHASAN}

\section{A. Konsistensi Pemerintah Pada Praktek Perkawinan Beda Agama}

Berdasarkan hasil penelitian di lapangan (Dinas Catatan Sipil Kota Makassar) ternyata pada tahun 2010 dan 2011 ada enam pasangan yang melakukan perkawinan beda agama dan mendapatkan penetapan dari pengadilan dan mencatatkan perkawinannya di Kantor Dinas Catatan Sipil Makassar.

Tabel 1. Jumlah perkawinan beda agama pada catatan sipil yang mendapatkan penetapan pengadilan.

Tahun 2010

\begin{tabular}{|l|l|l|}
\hline TANGGAL & PENETAPAN & PASAGAN \\
\hline 2/1/2010 & $\begin{array}{l}\text { No.172/pdt.p/2009/ } \\
\text { PN } \\
\text { Mks.30/12/2009 }\end{array}$ & $\begin{array}{l}\text { Raty Rasyid .S.E } \\
\text { dan Djulianty } \\
\text { andala .S.E }\end{array}$ \\
\hline 17/4/2010 & $\begin{array}{l}\text { No.58/pdt.p/2010 } \\
\text { Mks.12/4/2010 }\end{array}$ & $\begin{array}{l}\text { Tommy Alexander } \\
\text { jansz dan Suwarni }\end{array}$ \\
\hline 5/8/2010 & $\begin{array}{l}\text { No.106/pdt/2010 } \\
\text { Mks.28/6/2010 }\end{array}$ & $\begin{array}{l}\text { Sudiarjo .S.E dan } \\
\text { Lenny Christiyani } \\
\text { H }\end{array}$ \\
\hline
\end{tabular}

Tahun 2011

\begin{tabular}{|l|l|l|}
\hline TANGGAL & PENETAPAN & PASANGAN \\
\hline 29/4/2011 & $\begin{array}{l}\text { No.53/pdt.p/2011 } \\
\text { Mks. 11/4/2011 }\end{array}$ & $\begin{array}{l}\text { Valentino dan } \\
\text { Faridah }\end{array}$ \\
\hline $25 / 7 / 2011$ & $\begin{array}{l}\text { Neg,Maros. 04/ } \\
\text { pdt./2011 20/7/2011 }\end{array}$ & $\begin{array}{l}\text { Rachman sjah dan } \\
\text { hedy prisellia moka }\end{array}$ \\
\hline $27 / 12 / 2011$ & No.159/pdt.p/2011 & $\begin{array}{l}\text { Singgih yulianto dan } \\
\text { Selvina }\end{array}$ \\
\hline
\end{tabular}

Sumber data : Dinas Catatan Sipil Makassar, 2016

Dengan data pada tabel di atas meskipun sudah dilarang keberadaannya, pelaksanaan perkawinan beda agama masih saja terjadi di Kota Makassar, namun sampai saat ini masalah tersebut masih menjadi perdebatan boleh atau tidaknya perkawinan tersebut. Pada dasarnya perkawinan beda agama merupakan perkawinan yang tumbuh

5. Wanhar,"Semua Instansi Dilarang Fasilitasi Nikah Beda Agama” dalam- http://www.jpnn.com/read/2015/o6/22/310952/Semua-InstansiDilarang-Fasilitasi-Nikah-Beda Agama-, diunduh pada 21 Maret 2016. 
dan berkembang di dalam lingkungan masyarakat.

Jadi pada realitasnya, praktek perkawinan beda agama ini masih sering terjadi di masyarakat. Seperti yang dikemukakan oleh ibu Dra. Darmauli Hutagol selaku Kasi Perkawinan di Kantor Dinas Catatan Sipil Makassar (wawancara tatap muka tanggal 7 Januari 2016), mengatakan bahwa pasangan yang melakukan perkawinan beda agama tersebut, mereka sebenarnya sadar bahwa perbuatan yang mereka lakukan itu adalah perbuatan yang melawan hukum, baik itu hukum Negara ataupun hukum Agama. Akan tetapi keadaan yang mendorong mereka berbuat demikian. Mereka sadar bahwa perkawinan yang mereka lakukan mempunyai akibat yang tidak baik bagi mereka sendiri juga, berakibat bagi keturunan mereka nantinya. Tetapi alasan cinta lah yang paling utama penyebab mereka melakukan perkawinan beda agama. Pasangan beda agama yang pertama mengatakan bahwa, sebelum dewasa anak mereka dituntun akan dua agama yang berbeda, dan pada saat beranjak dewasa mereka menyerahkan sepenuhnya kepada anak mereka untuk memilih agama mana yang akan dianutnya. Sedangkan, pasangan beda agama yang kedua mengatakan bahwa, sebelum dewasa anak mereka dituntun secara Islam dan pada saat beranjak dewasa mereka juga menyerahkan sepenuhnya kepada anak mereka untuk memilih agama mana yang akan dianut, tetapi khusus bagi anak bungsu, akan menganut agama Kristen.

Tabel berikut akan memperlihatkan bentuk pemahaman masyarakat terhadap larangan perkawinan beda agama.

Tabel 2.Jawaban responden tentang apakah anda memahai/mengetahui tentang larangan praktek perkawinan beda agama.

\begin{tabular}{|l|l|l|l|}
\hline \multicolumn{1}{|c|}{ No. } & $\begin{array}{c}\text { Kategori } \\
\text { Jawaban }\end{array}$ & Frekuensi & Persentase \\
\hline 1. & Ya & 70 & $70 \%$ \\
2. & Tidak & 30 & $30 \%$ \\
Jumlah & & 100 & $100 \%$ \\
\hline
\end{tabular}

Sumber data: diolah berdasarkan hasil kuesioner, 2016

Menurut kenyataannya, bahwa pelaksanaan perkawinan beda agama masih banyak dilaksanakan di Kantor Dinas Catatan Sipil. Hal demikian, oleh karena hanya kantor catatan sipil yang mau melaksanakan perkawinan beda agama tersebut. Kantor Wilayah Kementerian
Agama Provinsi Sulawesi Selatan tidak berkenan melaksanakan perkawinan beda agama, oleh karena belum adanya kata sepakat dari para ahli hukum Islam tentang halal tidaknya perkawinan beda agama tersebut. Dengan mengajukan permohonan ke Pengadilan Negeri, dan permohonan tersebut dikabulkan dan dikeluarkannya penetapan Pengadilan, lalu Pengadilan Negeri memberi wewenang kepada Kantor Dinas Catatan Sipil untuk melangsungkan perkawinan beda agama dan mencatatkan perkawinan tersebut. Dalam hal pencatatan sendiri, perkawinan beda agama tersebut, dilakukan berdasarkan penetapan dari Pengadilan. Dengan dilakukannya pencatatan perkawinan, agar peristiwa tersebut menjadi jelas serta memenuhi syarat, dibuktikan dengan dikeluarkannya akta pernikahan dan segala konsekuensi baik bagi mempelai maupun bagi keturunannya dan masyarakat sekitarnya serta bagi semua pihak yang berkepentingan. Dengan adanya pencatatan perkawinan, maka perkawinan tersebut telah memenuhi ketentuan Pasal 2 Ayat 2 Undang-Undang No.1 Tahun 1974, yang berbunyi " tiap-tiap perkawinan dicatat menurut peraturan perundang-undangan yang berlaku”. Penolakan pencatatan perkawinan dikarenakan karena calon pasangan tersebut berbeda agama, menilai bahwa perkawinan tersebut bertentangan dengan peraturan perundang-undangan yang berlaku. Dari hasil penelitian yang dilakukan dilokasi penelitian, ditemukan 6 (enam) pasangan perkawinan beda agama yang dicatatkan di Kantor Dinas Catatan Sipil. Pencatatan perkawinan tersebut pada awalnya mendapat penolakan dari pihak Kantor Dinas Catatan Sipil, tetapi pasangan kawin beda agama tersebut mengajukan permohonan ke Pengadilan Negeri agar diberi penetapan. Adapun pertimbangan Hakim dalam memutus perkara tersebut antara lain :

1. Keterangan dari saksi-saksi, pada pokoknya menerangkan, bahwa :

a. Pemohon adalah pemeluk agama Islam.

b. Calon istri pemohon adalah pemeluk agama Kristen.

c. Antara pemohon denga calon istri, telah terjalin hubungan yang intim dan saling mencintai.

d. Antara orang tua pemohon dengan calon istri serta orang tua calon istri pemohon dengan pemohon sudah 
saling mengenal dan saling mengetahui hubungan mereka serta menyetujui akan rencana pernikahannya.

2. Berdasarkan Pasal 21 ayat (3) UndangUndang No.1 Tahun 1974, kepada para pihak yang perkawinannya ditolak, berhak mengajukan permohonan kepada Pengadilan di dalam wilayah mana pegawai pencatat perkawinan yang mengadakan penolakan berkedudukan untuk memberikan keputusan, dengan menyerahkan surat keterangan penolakan.

3. Berdasarkan Pasal 21 ayat (4) UndangUndang No.1Tahun 1974 tentang Perkawinan, pengadilan akan memeriksa perkaranya, dengan acara singkat dan akan memberikan ketetapan, apakah akan menguatkan penolakan tersebut atau memerintahkan agar perkawinan tersebut dilangsungkan.

4. Ketentuan dalam Pasal 27 Undang-Undang Dasar Negara Republik Indonesia Tahun 1945, yang menyatakan bahwa "segala warga Negara bersamaan kedudukannya di dalam hukum dan pemerintahan...", tercakup di dalam kesamaan hak asasi untuk kawin (the right of marry) dengan sesama warga Negara, sekalipun berbeda atau berlainan agama, selama Undang-Undang tidak menentukan bahwa perbedaan agama merupakan larangan untuk perkawinan, maka asas itu adalah sejalan dengan Pasal 29 UndangUndang Dasar Negara Republik Indonesia Tahun 1945, yang menyatakan "Negara menjamin kemerdekaan tiap-tiap penduduk untuk memeluk agamanya masing-masing dan untuk beribadat menurut agama dan kepercayaannya itu".

5. Hal ini sejalan dengan konvensi Hak Sipil dan Politik Perserikatan BangsaBangsa Tahun 1966, yang dalam Pasal 23 menyatakan tentang adanya hak untuk menikah dan berkeluarga bagi laki-laki dan perempuan dewasa untuk membentuk suatu keluarga harus diakui. Sementara pada Ayat (3) menyatakan bahwa, tidak ada perkawinan yang dapat dilakukan tanpa persetujuan yang bebas dan penuh dari kedua calon mempelai.
6. Di dalam Undang-Undang No.1 Tahun 1974, terdapat kekosongan hukum, dalam hal perkawinan calon suami dan istri yang berbeda agama.

7. Pasal 2 Ayat (1) Undang-Undang No.1 Tahun 1974 jo Pasal 10 Ayat (2) Peraturan Pemerintah Nomor 9 Tahun 1975, hanya berlaku bagi perkawinan antara dua orang yang sama agamanya.

8. Memperhatikan bunyi Pasal 3 dari penjelasan umum undang-undang perkawinan No.1 Tahun 1974 adalah "sesuai dengan landasan falsafah Pancasila dan Undang-Undang Dasar Negara Republik Indonesia Tahun 1945", maka Undang-Undang ini di satu pihak harus dapat mewujudkan prinsipprinsip yang terkandung dalam Pancasila dan Undang-Undang Dasar Negara Republik Indonesia Tahun 1945, sedangkan di lain pihak harus dapat pula menampung segala kenyataan yang hidup di dalam masyarakat dewasa ini. Undang-Undang No.1 Tahun 1974 telah menampung di dalamnya unsurunsur dan ketentuan hukum agamanya itu dari yang bersangkutan.

9. Dari penjelasan umum tersebut, menimbulkan konsekuensi perlunya menentukan tentang kekosongan hukum tersebut, karena secara sosiologis suatu undang-undang yang tidak menampung kenyataan yang hidup dalam masyarakat, akan menjadi suatu peraturan perundang-undangan yang mati atau black letter law. Dengan demikian akan menjadi sukar untuk mencapai taraf kepatutan terhadap hukum tertulis.

10. Tidak mengakui adanya perkawinan antar agama, sebagai suatu kenyataan pada masyarakat dan tidak memberi tempat untuk adanya pengaturan terhadap perkawinan tersebut, di dalam Undang-Undang No.1 Tahun 1974, bertentangan dengan bunyi angka 3 penjelasan umumnya dan mengingkari kemungkinan timbulnya masalah yang telah diciptakan dengan rumusan Pasal 2 Ayat (1).

11. Bagi pemohon yang beragama islam dan yang akan melangsungkan perkawinan di hadapan Pegawai Pencatat Nikah, Talak dan Rujuk, pemohon hanya dapat melangsungkan 
perkawinan di hadapan Pegawai Pencatatan Perkawinan pada Kantor Dinas Catatan Sipil.

12. Niat perkawinan antar agama telah menjadi kenyataan, dan tidaklah dapat dibenarkan adanya kepastian hukum terhadap perkawinan antar agama, berarti tidak memberikan perlindungan hukum kepada warga Negara dan hal ini tidak sejalan dengan tujuan hukum dan Negara Republik Indonesia, yang ber-Pancasila dan ber-Undang-Undang Dasar Negara Republik Indonesia Tahun 1945.

Wawancara tatap muka yang dilakukan terhadap masyarakat yang bernama Nadia (tanggal 28 Juli 2016), mengatakan bahwa pemerintah tidak konsisten dalam menyikapi praktek perkawinan beda agama yang terjadi. Hal ini dikarenakan tidak adanya sinergitas antara masing-maing lembaga yang berwenang. Ada lembaga yang mengizinkan, memberikan penetapan, mencatatkan, bahkan melaksanakan perkawinan beda agama tersebut dan ada pula yang dengan tegas melarang. Sinergitas sangat diperlukan untuk mengatasi masalah ini, agar masyarakat dapat sadar bahwa perkawinan beda agama itu benar-benar dilarang.

Tabel 3. Jawaban responden tentang apakah pemerintah konsisten dalam menyikapi praktek perkawinan beda agama.

\begin{tabular}{|l|l|l|l|}
\hline No. & $\begin{array}{l}\text { Kategori } \\
\text { Jawaban }\end{array}$ & Frekuensi & Persentase \\
\hline 1. & Konsisten & 40 & $40 \%$ \\
2. & Tidak Konsisten & 60 & $60 \%$ \\
\multicolumn{2}{|l}{ Jumlah } & 100 & $100 \%$ \\
\hline
\end{tabular}

Sumber data: diolah berdasarkan hasil kuesioner, 2016

Dengan pertimbangan-pertimbangan seperti yang disebutkan tersebut, maka Hakim menetapkan memerintahkan Kantor Dinas Catatan Sipil, agar supaya melangsungkan perkawinan setelah terpenuhinya syarat-syarat perkawinan menurut Undang-Undang dan mencatatkan perkawinan tersebut. Hakim yang berkewajiban untuk menciptakan hukum guna memenuhi rasa keadilan masyarakat dan juga memperhatikan pertimbangan yurisprudensi tentang perkawinan beda agama, yang pada umumnya dapat mengabulkan pencatatan perkawinan beda agama untuk memenuhi rasa keadilan.

Dengan melihat pertimbangan-petimbangan Hakim dalam memutuskan perkara tersebut, dapat disimpulkan bahwa dalam UU No.1 Tahun 1974 tentang Perkawinan, tidak mengatur secara tegas mengenai perkawinan beda agama. Maka dalam hal perkawinan beda agama ada kekosongan hukum untuk menyelesaikannya, sehingga diperlukan penciptaan hukum oleh Hakim untuk penyelesaian perkara tersebut. Dalam hal penetapan yang dikeluarkan oleh Pengadilan, Hakim juga memperhatikan pertimbangan yurisprudensi tentang perkawinan beda agama, sehingga perkawinan tersebut dapat dicatatkan di Kantor Dinas Catatan Sipil.

Tabel 4. Jawaban responden tentang bagaimanakah kepastian hukum tentang larangan praktek perkawinan beda agama.

\begin{tabular}{|l|l|l|l|}
\hline No. & $\begin{array}{r}\text { Kategori } \\
\text { Jawaban }\end{array}$ & Frekuensi & Persentase \\
\hline 1. & Jelas & 30 & $30 \%$ \\
2. & Tidak Jelas & 70 & $70 \%$ \\
Jumlah & 100 & $100 \%$ \\
\hline
\end{tabular}

Sumber data: diolah berdasarkan hasil kuesioner, 2016

\section{B. Pengaruh Perkawinan Beda Agama Dalam Keluarga}

Pada dasarnya perkawinan bertujuan untuk membentuk suatu keluarga yang sakinah yang berlandaskan agama yang baik. Anak yang merupakan anugerah dari perkawinan dengan penuh harapan dapat menjadi penerus dan kebanggaan keluarga. Demi terwujudnya harapan tersebut tentu saja seorang anak harus dibekali dengan pendidikan yang baik. Dengan pendidikan tersebut seorang anak mendapatkan pemahaman yang paling dasar tentang mana yang baik dan mana yang buruk. Sejak usia dini seorang anak haruslah mendapatkan pendidikan, baik itu pendidikan formal ataupun informal. Dalam hal ini ayah dan ibu selain bertindak sebagai orang tua juga haruslah bertindak sebagai guru bagi anak-anaknya dengan memberikan pemahaman yang paling mendasar adalah pendidikan agama. Pendidikan agama tentu tidak menjadi persoalan ketika orang tua memiliki iman yang sama, akan tetapi bagaimana dengan orang tua yang tidak seiman? Hal ini tentu akan memberikan persoalan tersendiri bagaimana mendidik anak-anak mereka. Egoisme yang muncul terkait agama mana yang harus diajarkan kepada anak-anak mereka akan memberikan dampak yang negatif bagi perkembangan religius dan psikologi anak. 
Penentuan anak akan dibesarkan dalam agama mana akan menjadi persoalan yang serius. Selain itu keluarga besar dari masing-masing pasangan umumnya akan terlibat dalam memperebutkan agama anak. Anak yang beranjak dewasa akan mengalami dilema yang besar dalam menentukan agamanya.

Dampak negatif yang ditimbulkan dari perkawinan beda agama memilik konsekuensi yang besar dan dampak yang panjang. Baik secara religius dan psikologis baik itu terhadap pasangan beda agama dan anak. Menurut hukum, anak yang dilahirkan oleh pasangan yang berbeda agama tidak lah sah secara yuridis. Karena anak yang sah menurut Undang-Undang Perkawinan Pasal 42 ialah anak yang lahir dari perkawinan yang sah. Perkawinan yang sah dalam Pasal 2 Ayat (1) adalah yang dilakukan berdasarkan hukum masing-masing agama dan kepercayaan. Masalah lain yang ditimbulkan adalah masalah warisan. Misalnya suami beragama Islam dan isteri serta anak-anaknya beragama non-Islam maka, sudah tentu merupakan halangan bagi Islam untuk menerima maupun mewarisi harta warisannya. ${ }^{6}$ Secara psikologis masalah anak yang lahir dari perkawinan beda agama tidak memiliki pemahaman tentang agama dan status agama dari orang tuanya, dikarenakan orang tua tidak terbuka sebab terjadi kebingungan pada orang tua bahwa anak akan dibesarkan mengacu atas agama yang mana. Bossard dan Boll menyebutkan ada banyak tantangan yang dihadapi oleh keluarga yang di dalamnya terdapat perbedaan agama antara pasangan. Mulai dari konflik antara pasangan, konflik dengan orang-orang di luar pasangan, penentuan agama anak dan cara anak dibesarkan. Tantangan terakhir merupakan permasalahan yang paling melibatkan emosi karena menyangkut kepentingan banyak pihak dan hal prinsipil.

Pada akhirnya perkawinan beda agama yang didasari atas cinta yang besar seiiring bertambahnya usia akan menimbulkan rasa penyesalan dan pemikiran akan adanya kehidupan yang kekal berdasarkan hukum agama dan bersumber dari Tuhan. Persoalan-persoalan kecil yang timbul lama kelamaan akan membesar dan menjadi indikator utama untuk mengakhiri perkawinan beda agama tersebut. Wawancara tatap muka yang dilakukan terhadap masyarakat $\mathrm{M}$. Adam Ikhsan (tanggal 30 Juli 2016) mengatakan bahwa, perkawinan beda agama bukanlah sebuah solusi yang baik. Kehidupan ini bukan hanya sekedar hal-hal yang berbau duniawi, akan tetapi ada kehidupan kedua yang kekal nantinya, dan itu bersumber dari Tuhan. Sebuah perkawinan adalah hal yang wajib dilakukan setiap agama, karena maksud dan tujuannya yang begitu baik, akan tetapi kita sebagai manusia harus bijak dalam melangkah dan mengambil keputusan, karena kehidupan ini syarat akan nilai-nilai agama yang mengikat. Selanjutnya wawancara tatap muka yang dilakukan terhadap masyarakat, Muslim (tanggal 2 Agustus 2016) mengatakan bahwa, perkawinan beda agama bukanlah hal yang benar sebab ketentuan atas hukum tersebut sudah diatur, dan dampak terhadap anak kelak yang menjadi persoalan terkait status agama anak. Selanjutnya pula wawancara tatapmuka yang dilakukan oleh masyarakat, Kiki Amelia (tanggal 8 Agustus 2016) mengatakan bahwa persoalan status agama anak lah yang menjadi persoalan. Kiki beranggapan bahwa awalnya pasangan akan konsisten dengan kesepakatan awal yang telah dijanjikan soal anak, akan tetapi seiring waktu sifat egoisme akan muncul terkait hak asuh anak, dan status agama anak nantinya.

Suatu perkawinan tentunya selalu menimbulkan akibat hukum dan apabila perkawinan tersebut adalah perkawinan beda agama tentunya akan menimbulkan berbagai masalah. Masalah-masalah tersebut menyangkut hubungan-hubungan suami isteri dan berimbas kepada anak-anak apabila memiliki keturunan. Akibat hukum disini dibagi menjadi dua bagian yaitu menurut aspek psikologis dan aspek yuridis. Dari aspek psikologis misalnya, Pasangan yang kawin beda agama yang awalnya hanya didasari dengan rasa cinta, lama kelamaan seiring bertambahnya usia yang semakin dewasa tentunya akan mengarah pada pemikiran tentang adanya kebahagiaan yang kekal menurut ajaran agama. Belum lagi dalam hal mengajarkan ajaran agama kepada anak, tentu menjadi dilematis ajaran agama apakah yang hendak diajarkan. Lama kelamaan

6. Jane Marlen Makalew, Akibat Hukum Dari Perkawinan Beda Agama di Indonesia, dalam jurnal Lex Privatum Vol. 1/No.2/April-Juni, 2013, h. 142 
akan timbul sifat egoisme masing-masing dalam hal anak akan memeluk ajaran agama yang mana. ${ }^{7}$

Tabel 5. Jawaban responden tentang pengaruh apakah yang ditimbulkan dari perkawinan beda agama.

\begin{tabular}{|l|l|l|l|}
\hline No. & $\begin{array}{r}\text { Kategori } \\
\text { Jawaban }\end{array}$ & Frekuensi & Persentase \\
\hline 1. & Baik & 30 & $30 \%$ \\
2. & Tidak Baik & 70 & $70 \%$ \\
Jumlah & 100 & $100 \%$ \\
\hline
\end{tabular}

Sumber data: diolah berdasarkan hasil kuesioner, 2016

Perkawinan Beda Agama Menurut Beberapa Pandangan Agama

Perkawinan merupakan naluri manusia sejak adanya manusia itu sendiri untuk memenuhi hajat kehidupannya dalam melakukan hubungan biologis dalam berkeluarga. Tentu saja dalam pernikahan itu menyangkut sedikitnya hubungan antar dua pihak, yang dalam istilah hukum disebut hubungan hukum, dimana masing-masing pihak mempunyai hak dan kewajiban, maka timbul hukum objektif yang mengaturnya yang disebut hukum perkawinan. Oleh karena itu, bagi para pemeluk agama, perikatan perkawinan bukan dianggap perikatan biasa, tetapi bersifat sakral yang mengandung ajaran-ajaran agama bagi pemeluknya, tentu saja mereka tidak dapat melepaskan diri pada ketentuan-ketentuan hukum objektif yang diatur dalam agama masing-masing. ${ }^{8}$

Atas landasan itu, maka dirumuskan UU No. 1 Tahun 1974 tentang Perkawinan yang dalam Pasal 1 berbunyi:

" Perkawinan adalah ikatan lahir batin antara seorang pria dan seorang wanita sebagai suami istri dengan tujuan membentuk keluarga (rumah tangga) yang bahagia dan kekal berdasarkan Ketuhanan Yang Maha Esa".

Selanjutnya dalam Pasal 2 dinyatakan :

"Perkawinan adalah sah apabila dilakukan menurut hukum masing-masing agama dan kepercayaan itu".
Adanya ketentuan, bahwa sahnya perkawinan apabila dilakukan oleh masing-masing agamanya dan kepercayaanya itu" dan dalam Penjelasan tersebut ditegaskan, bahwa tidak ada perkawinan di luar hukum masing-masing agamanya, jelas bahwa perkawinan antar agama tidak sah dan bukan perkawinan. Membuat ketentuan untuk melegalisasikan perkawinan antar agama berarti membiarkan orang untuk merusak integritas masing-masing agama serta bertentangan dengan kesadaran hukum dan keyakinan hukum bangasa Indonesia dan tentu saja bertentangan dengan Pancasila dan Undang-Undang Dasar Negara Republik Indonesia Tahun 1945 serta UU No. 1 Tahun 1974 tentang Perkawinan, dan tentu saja bertentangan dengan Al-Quran dan Hadits.

Berikut beberapa pandangan agama tentang perkawinan beda agama tersebut:

\section{Pandangan Agama Islam}

Pandangan Agama Islam terhadap perkawinan antar agama, pada prinsipnya tidak memperkenankannya. Dalam Alquran dengan tegas dilarang perkawinan antara orang Islam dengan orang musrik seperti yang tertulis dalam Al-Quran yang berbunyi:

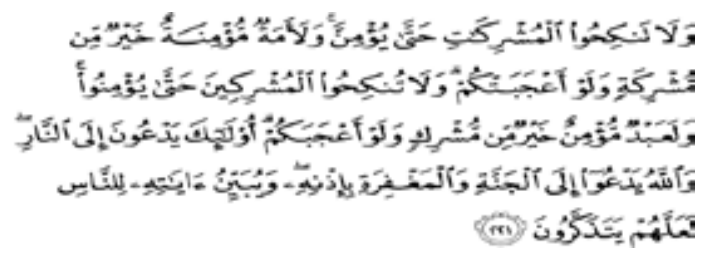

Artinya :"Janganlah kamu nikahi wanitawanita musrik sebelum mereka beriman. Sesungguh nya wanita budak yang mukmin lebih baik dari wanita musyrik, walupun dia menarik hati.Dan janganlah kamu menikahkah orang musyrik (dengan wanitawanita mukmin) sebelum mereka beriman. Sesungguhnya budak yang mukmin lebih baik daripada orang musyrik, walaupun dia menarik hatimu”.' (Q.S.Al-Baqarah [2]:221)

Larangan perkawinan dalam Q.S. Al-Baqarah ayat 221 itu berlaku bagi laki-laki maupun wanita yang beragama Islam untuk kawin dengan orangorang yang tidak beragama Islam.

7. Jane Marlen Makalew, Akibat Hukum Dari Perkawinan Beda Agama Di Indonesia, dalam jurnal Lex Privatum Vol. 1/No.2/April-Juni, 2013, h. 131

8. Munir, "Perkawinan Beda Agama Dalam Perspektif Agama-Agama” dalam-“mediadakwah.net/zaldym.wordpress.com, diunduh pada 22 Maret 2016. 


\section{Pandangan Agama Katolik}

Salahsatuhalanganyangdapatmengakibatkan perkawinan tidak sah, yaitu perbedaan agama. Bagi Gereja Katholik menganggap bahwa perkawinan antar seseorang yang beragama katholik dengan orang yang bukan katholik, dan tidak dilakukan menurut hukum agama Katholik dianggap tidak sah. Disamping itu, perkawinan antara seseorang yang beragama Katholik dengan orang yang bukan Katholik bukanlah merupakan perkawinan yang ideal. Hal ini dapat dimengerti karena agama Katholik memandang perkawinan sebagai sakramen sedangkan agama lainnya (kecuali Hindu) tidak demikian karena itu Katholik menganjurkan agar penganutnya kawin dengan orang yang beragama katholik.

\section{Pandangan Agama Protestan}

Pada prinsipnya agama Protestan menghendaki agar penganutnya kawin dengan orang yang seagama, karena tujuan utama perkawinan untuk mencapai kebahagiaan sehingga akan sulit tercapai kalau suami istri tidak seiman. Dalam hal terjadi perkawinan antara seseorang yang beragama Protestan dengan pihak yang menganut agama lain, mereka dianjurkan untuk menikah secara sipil di mana kedua belah pihak tetap menganut agama masing-masing. Kepada mereka diadakan pengembalaan khusus. Pada umumnya gereja tidak memberkati perkawinan mereka. Ada gerejagereja tertentu yang memberkati perkawinan beda agama ini, setelah pihak yang bukan protestan membuat pernyataan bahwa ia bersedia ikut agama Protestan. Keterbukaan ini dilatarbelakangi oleh keyakinan bahwa pasangan yang tidak seiman itu dikuduskan oleh suami atau isteri yang beriman. Ada pula gereja tertentu yang bukan hanya tidak memberkati, malah anggota gereja yang kawin dengan orang yang tidak seagama itu dikeluarkan dari gereja.

\section{Pandangan Agama Hindu}

Perkawinan orang yang beragama Hindu yang tidak memenuhi syarat dapat dibatalkan. Dalam Agama Hindu suatu perkawinan batal karena tidak memenuhi syarat bila perkawinan itu dilakukan menurut Hukum Hindu tetapi tidak memenuhi syarat untuk pengesahannya, misalnya mereka tidak menganut agama yang sama pada saat upacara perkawinan itu dilakukan, atau dalam hal perkawinan antar agama tidak dapat dilakukan menurut hukum agama Hindu.

Dari uraian di atas dapat diketahui bahwa untuk mensahkan suatu perkawinan menurut agama Hindu, harus dilakukan oleh Pedande/Pendeta yang memenuhi syarat untuk itu. Di samping itu tampak bahwa dalam hukum perkawinan Hindu tidak dibenarkan adanya perkawinan antar penganut agama Hindu dan bukan Hindu yang disahkan oleh Pedande. Dalam agama Hindu tidak dikenal adanya perkawinan antar agama. Hal ini terjadi karena sebelum perkawinan harus dilakukan terlebih dahulu upacara keagamaan. Apabila salah seorang calon mempelai tidak beragama Hindu, maka dia diwajibkan sebagai penganut agama Hindu, karena kalau calon mempelai yang bukan Hindu tidak disucikan terlebih dahulu dan kemudian dilaksanakan perkawinan, hal ini melanggar ketentuan dalam Seloka V89 kitab Manawadharmasastra, yang berbunyi:

"Air pensucian tidak bisa diberikan kepada mereka yang tidak menghiraukan upacaraupacara yang telah ditentukan, sehingga dapat dianggap kelahiran mereka itu siasia belaka, tidak pula dapat diberikan kepada mereka yang lahir dari perkawinan campuran kasta secara tidak resmi, kepada mereka yang menjadi petapa dari golongan murtad dan pada mereka yang meninggal bunuh diri."

Terakhir dapat disimpulkan bahwa perkawinan antar agama dimana salah satu calon mempelai beragama Hindu tidak boleh dan pendande/Pendeta akan menolak untuk mengesahkan perkawinan tersebut.

\section{Pandangan Agama Budha}

Perkawinan antar agama di mana salah seorang calon mempelai tidak beragama Budha, menurut keputusan Sangha Agung Indonesia diperbolehkan, asal pengesahan perkawinannya dilakukan menurut cara agama Budha. Dalam hal ini calon mempelai yang tidak bergama Budha, tidak diharuskan untuk masuk agama Budha terlebih dahulu. Akan tetapi dalam upacara ritual perkawinan, kedua mempelai diwajidkan mengucapkan "atas nama Sang Budha, Dharma dan Sangka" yang merupakan dewa-dewa umat Budha.

Dari uraian di atas dapat disimpulkan bahwa agama Budha tidak melarang umatnya untuk melakukan perkawinan dengan penganut agama lain. Akan tetapi kalau penganut agama lainnya maka harus dilakukan menurut agama Budha. 
Di samping itu, dalam upacara perkawinan itu kedua mempelai diwajibkan untuk mengucapkan atas nama Sang Budha, Dharma dan Sangka, ini secara tidak langsung berarti bahwa calon mempelai yang tidak beragama Budha menjadi penganut agama Budha, walaupun sebenarnya ia hanya menundukkan diri pada kaidah agama Budha pada saat perkawinan itu dilangsungkan. Untuk menghadapi praktek perkawinan yang demikian mungkin bagi calon mempelai yang tidak beragama Budha akan merasa keberatan.

Dari beberapa pandangan tersebut, hampir semua agama pada dasarnya melarang adanya praktek perkawinan beda agama karena masalah perkawinan adalah ketentuan hukum alam (Tuhan). Aristoteles mengatakan bahwa hukum alam sebagai hukum yang asli berlaku dimana saja, orang-orang yang berpikiran sehat merasakan hukum alam selaras dengan kodrat manusia. Hukum alam selalu eksis dalam kehidupan hukum dan masyarakat adalah karena hukum alam memang ada basisnya dalam suatu masyarakat. ${ }^{9}$

Negara dalam hal ini kapasitasnya selaku pembuat kebijakan dalam hal perkawinan, haruslah mengacu kepada hukum masing-masing agama sebab Negara adalah wakil Tuhan di dunia ini. Menurut Friedrich Stahl bahwa Negara adalah merupakan wakil Tuhan sehingga Negara mempunyai kewenangan untuk menyelenggarakan tata tertib di dunia ini. Sementara hukum itu adalah perintah Tuhan, maka manusia mentaati hukum pada hakekatnya mentaati perintah Tuhan. ${ }^{10}$

\section{KESIMPULAN}

Dari uraian analisis data dalam bab hasil penelitian, tidak konsistensinya implementasi Undang-undang Nomor 1 Tahun 1974 tentang Perkawinan dalam menyikapi praktek perkawinan beda agama di Kota Makassar. Ini terbukti dengan dilaksanakannya perkawinan beda agama terhadap 6 pasangan oleh Dinas Catatan Sipil Kota Makassar setelah pelaku prakter perkawinan beda agama mendapatkan penetapan dari Pengadilan Negeri setempat. Hal tersebut tentu tidak terintegrasi dengan aturan-aturan hukum yang ada walaupun ada beberapa kebijakan dalam aturan agama. Timbulnya kebijakan bagi perkawinan beda agama, dilihat dari hukum agama masingmasing. Tidak dapat diproses suatu perkawinan beda agama kecuali ada dispensasi dari hukum agama. Agama Islam sendiri memberikan kebijakan kepada umatnya yang pria untuk dapat kawin dengan wanita yang bukan Islam dengan alasan dan tujuan agar calon istri kelak memeluk agama Islam, sehingga pihak dari Negara sendiri mau melangsungkan perkawinan beda agama tersebut. Agama Islam tidak memberi kebijakan kepada umatnya yang wanita untuk kawin dengan pria yang bukan Islam, sehingga dalam hal ini tentu negara juga melarang perkawinan tersebut. Dengan adanya putusan tersebut maka jelas bahwa tidak adanya konsistensi pemerintah dalam mencegah kasus perkawinan beda agama. Kantor Catatan Sipil sendiri hanya berwenang untuk mencatatkan perkawinan. Dinas Catatan Sipil menolak mencatatkan perkawinan yang berbeda agama, akan tetapi dengan adanya penetapan dari Pengadilan Negeri yang memberi wewenang kepada Kantor Catatan Sipil untuk melangsungkan dan mencatatkan perkawina beda agama, sehingga biasanya Kantor Dinas Catatan Sipil menjadi tempat dilangsungkannya perkawinan beda agama.

Pengaruh negatif yang timbul dalam perkawinan beda agama adalah terkait status agama anak. Anak adalah harapan cita-cita dapat menjadi penerus yang baik akan mengalami tekanan dan dilema, sehingga tumbuh kembang anak akan berpengaruh negatif terhadap religi dan psikologi anak. Perkawinan beda agama akan memiliki konsekuensi jangka panjang dari sisi emosional dan hal-hal yang prinsipal. Banyak tantangan yang akan dihadapi keluarga, mulai dari konflik antar pasangan, konflik dengan keluarga dari masing-masing pasangan, status agama anak, hak mewaris anak dan cara anak dibesarkan.

\section{SARAN}

Pengaturan mengenai perkawinan beda agama, harus diatur secara tegas di dalam peraturan Perundang-undangan, sehingga tidak menimbulkan penafsiran hukum yang berakibat adanya kebingungan pada masyarakat yang terkait dengan permasalahan tersebut dan konsistensi pemerintah harus dipertegas lagi. Penetapan yang

9. Munir Fuady, Teori-Teori Besar (Grand Theory) Dalam Hukum, (Jakarta:Kencana Prenadamedia Group, 2014 ), h. 13.

10. Said Sampara dkk, Buku Ajar Pengantar Ilmu Hukum, (Makassar : Kretakupa Print, 2014), h. 51 
diberikan pengadilan terhadap perkawinan beda agama, perlu dikaji lagi secara lebih spesifik. Penetapan yang diberikan haruslah sesuai dengan aturan agama dan perundang-undangan yang berlaku dan adanya penyuluhan tentang perkawinan beda agama, sehingga masyarakat dapat memperoleh informasi yang lebih jelas tentang pelaksanaan dan konsekuensinya.

Para pelaku perkawinan beda agama harus lebih bijak dalam mengambil keputusan. Persoalannya adalah selain pada pasangan juga pada anak hasil dari perkawinan tersebut. Konsekuensi jangka panjang yang ditimbulkan dari perkawinan tersebut berpengaruh negatif dari sisi emosional dan ha-hal prinsipal, terkhusus pada perkembangan religi dan psikologi anak. 


\section{DAFTAR PUSTAKA}

\section{Buku:}

Abdurrahman, Kompilasi Hukum Islam Indonesia, Jakarta : Akademika Pressindo, 2010.

Bossard, J. \& Boll, E. One Marriage Two Faith;Guindance on interfaith marriage, New York : The Ronald Press, 1957.

Fuady, Munir, Teori-Teori Besar (Grand Theory) Dalam Hukum, Jakarta:Kencana Prenadamedia Group, 2014

Hadikusuma, Hilman, Hukum Perkawinan Indonesia menurut Perundangan Hukum Adat Hukum Agama, Bandung : Mandar Maju, 2007.

Manan, Abdul, Aneka Masalah Hukum Perdata Islam di Indonesia,Jakarta :Kencanaprenada Media Group, 2008.

Sampara, Said dkk, Buku Ajar Pengantar Ilmu Hukum, Makassar : Kretakupa Print, 2014.

\section{Jurnal:}

Makalew, Jane Marlen, Akibat Hukum Dari Perkawinan Beda Agama Di Indonesia, dalam jurnal Lex Privatum Vol. 1/No.2/AprilJuni, 2013.

\section{Sumber lain:}

Wanhar,"Semua Instansi Dilarang Fasilitasi Nikah BedaAgama"dalam http://www.jpnn.com/ $\mathrm{read} / 2015 / 06 / 22 / 310952 / S e m u a-I n s t a n s i-$ Dilarang-Fasilitasi-Nikah-BedaAgama-, diunduh pada 21 Maret 2016.

Munir, "Perkawinan BedaAgama Dalam Perspektif Agama-Agama"dalam "mediadakwah.net/ zaldym.wordpress.com(2008), diunduh pada 22 Maret 2016.

\section{Peraturan Perundang-Undangan:}

Undang-Undang Nomor 1 Tahun 1974 Tentang Perkawinan (Lembaran Negara Republik Indonesia Tahun 1974 Nomor 1) 